\title{
Mycological Diversity Description I
}

\author{
Jadson Diogo Pereira Bezerra* (D), Alexandre Reis Machado ${ }^{1}$ (D), André Luiz Firmino ${ }^{2}$ (D), André Wilson Campos \\ Rosado $^{3}$ (D), Carlos Alberto Fragoso de Souza ${ }^{1}$, Cristina Maria de Souza-Motta ${ }^{1}$, Karla Torres Lins de Sousa

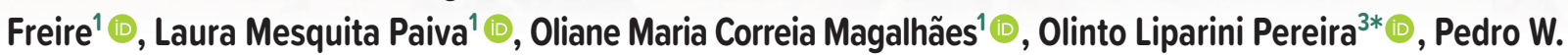 \\ Crous $^{4}{ }^{(D)}$, Thays Gabrielle Lins de Oliveira ${ }^{1}$, Vanessa Pereira de Abreu ${ }^{5}\left(\mathbb{D}\right.$ and Xinlei Fan ${ }^{6}$ (D)
}

Received: October 25, 2017

Accepted: May 17, 2018

\begin{abstract}
Here, Quambalaria fabacearum and Neopestalotiopsis brasiliensis are introduced as new species from Brazil, isolated as endophyte from Mimosa tenuiflora and causing post-harvest rot disease on fruits of Psidium guajava, respectively. Diaporthe inconspicua is emended to include a more detailed morphological description. Neopestalotiopsis egyptiaca is reported as new to the Americas and as causing post-harvest rot disease on fruits of Psidium guajava, while Umbelopsis isabellina is reported as endophyte.
\end{abstract}

Keywords: Amphisphaeriales, CaM, Diaporthales, H3, ITS rDNA, LSU rDNA, Microstromatales, TUB2, tef1- $\alpha$, Umbelopsidales

\section{Quambalaria fabacearum J.D.P. Bezerra, Firmino,} Souza-Motta \& Crous, sp. nov.

MycoBank MB 823271, Fig. 1

Etymology: The name refers to the host plant family, Fabaceae.

Description: Mycelium superficial to partially immersed; hyphae hyaline, smooth, branched, loosely septate, 1.5$2.5 \mu \mathrm{m}$ wide. Conidiophores similar to hyphae, scattered, cylindrical, terminal or as short side branches, hyaline, smooth, 0-2-septate, rarely 3-septate, (12-) 14-58 (-106) × $1.5-2.5 \mu \mathrm{m}(\mathrm{n}=20)$. Conidiogenous cells cylindrical, terminal or integrated, (5.5-) 9.5-13 (-34) × 1-2 $\mu \mathrm{m}(\mathrm{n}=20)$, straight to curved, forming conidia by sympodial growth consisting of a slightly swollen cluster of small conidium bearing denticles; conidiogenous loci denticulate, inconspicuous, pointed or flattened. Conidia hyaline, non-septate, smooth, occasionally guttulate; primary conidia ellipsoidal to fusoid or obovoid, $7.5-8.5 \times 1.5-2.5 \mu \mathrm{m}(\mathrm{n}=30)$, with basal scar or scars at both ends, often giving rise to one or several obovoid or narrowly ellipsoidal secondary conidia, (3.5-)

\footnotetext{
1 Departamento de Micologia, Universidade Federal de Pernambuco, 50670-901, Recife, PE, Brazil

2 Instituto de Ciências Agrárias, Universidade Federal de Uberlândia, 38500-000, Monte Carmelo, MG, Brazil

3 Departamento de Fitopatologia, Universidade Federal de Viçosa, 36570-000, Viçosa, MG, Brazil

4 Westerdijk Fungal Biodiversity Institute, 3508 AD, Utrecht, The Netherlands

5 Departamento de Microbiologia, Universidade Federal de Viçosa, 36570-000, Minas Gerais, Brazil

6 The Key Laboratory for Silviculture and Conservation of the Ministry of Education, Beijing Forestry University, 100083, Beijing, China

* Corresponding authors: JDPB: jadsondpb@gmail.com, OLP: oliparini@ufv.br
} 
4.5-5.5 $(-6.5) \times 1.5-2 \mu \mathrm{m}(\mathrm{n}=30)$. Chlamydospores rarely observed. Sexual morph not observed.

Cultures (in the dark, $25^{\circ} \mathrm{C}, 2 \mathrm{wk}$ ): Colonies on PDA growing up to $25 \mathrm{~mm}$ diam., finely floccose, zonate, surface white with slightly yellowish color in the middle, reverse yellowish to sienna, with a yellowish ring at the end of the colonies, without any odor; yellow pigment produced in culture medium and a slightly brownish pigment surrounding the culture. After $30 \mathrm{~d}$, colonies are slightly cream-coloured on the surface, reverse dark brown, and a sienna-rust pigment is produced in the medium. Colonies on MEA growing up to $25 \mathrm{~mm}$ diam., finely floccose, zonate, surface white and slightly cream-coloured, yellowish in the middle, reverse yellowish brown, without any odour.

Type: BRAZIL. Paraíba: Santa Teresinha, Tamanduá farm $\left(7^{\circ} 1.524^{\prime} \mathrm{S} 37^{\circ} 23.518^{\prime} \mathrm{W}\right)$, isolated as endophyte from branches of Mimosa tenuiflora (Willd.) Poir. (Fabaceae), May 2013, J.D.P. Bezerra (Holotype URM 90895; Culture ex-type URM 7756).

GenBank accession numbers: URM 7756 (ex-type): ITS MG253664, LSU MG253665.

Notes - Based on the phylogenetic analyses, the new species, Quambalaria fabacearum, is closely related to $Q$. cyanescens (Fig. 2). Morphologically, Q. fabacearum differs from $Q$. cyanescens mainly in the size of the conidiogenous cells ((5.5-) 9.5-13 (-34) × 1-2 $\mu \mathrm{m}$ in $Q$. fabacearum vs. $30-40 \times 1.5-3$ in $Q$. cyanescens $)$, primary conidia $(7.5-8.5 \times 1.5-2.5 \mu \mathrm{m}$ in Q. fabacearum vs. 3.5-6.5 $(-25) \times 2.5-3.5$ in $Q$. cyanescens $)$, secondary conidia ((3.5-) 4.5-5.5 (-6.5) $\times 1.5-2 \mu \mathrm{m}$ in $Q$. fabacearum vs. $2.5-3.5 \times 2-2.5$ in $Q$. cyanescens), and in the presence of chlamydospores in $Q$. fabacearum. Furthermore, these species differ in culture characteristics with the production of a pale yellowish pigment by $Q$. fabacearum when cultured on PDA, and a purple pigment produced by Q. cyanescens (Hoog \& Vries 1973; Paap et al. 2008). The genus Quambalaria was proposed by Simpson (2000) to accommodate species pathogenic to Eucalyptus previously circumscribed as Ramularia and Sporothrix. Later, de Beer et al. (2006) proposed a new family, Quambalariaceae, to accommodate Quambalaria, which was placed in a monophyletic clade in the Microstromatales. Six species of Quambalaria are presently listed in Index Fungorum and MycoBank, being chiefly associated with leaf and shoot diseases of Myrtaceae (Eucalyptus and Corymbia) (Hoog \& Vries 1973; Simpson 2000; Beer et al. 2006; Paap et al. 2008; Cheewangkoon et al. 2009). Quambalaria pusilla is the only species without DNA data available (Beer et al. 2006), but it differs morphologically from $Q$. fabacearum mainly in the size of the conidiophores $(5-25 \times 1-2 \mu \mathrm{m})$, and primary $(4-10 \times 1-2 \mu \mathrm{m})$ and secondary conidia $(1.5-3.5 \times 0.5-$ $1.5 \mu \mathrm{m}$ ) (Braun 1998). Besides species of Quambalaria being reported as pathogenic to plants, $Q$. cyanescens is the only species thus far to be associated with human infections, although they are believed to be opportunistic infections, or as a environmental contaminant (Hoog \& Vries 1973; Fan et al. 2014). Quambalaria fabacearum is reported here as endophyte, representing the first record from Fabaceae.

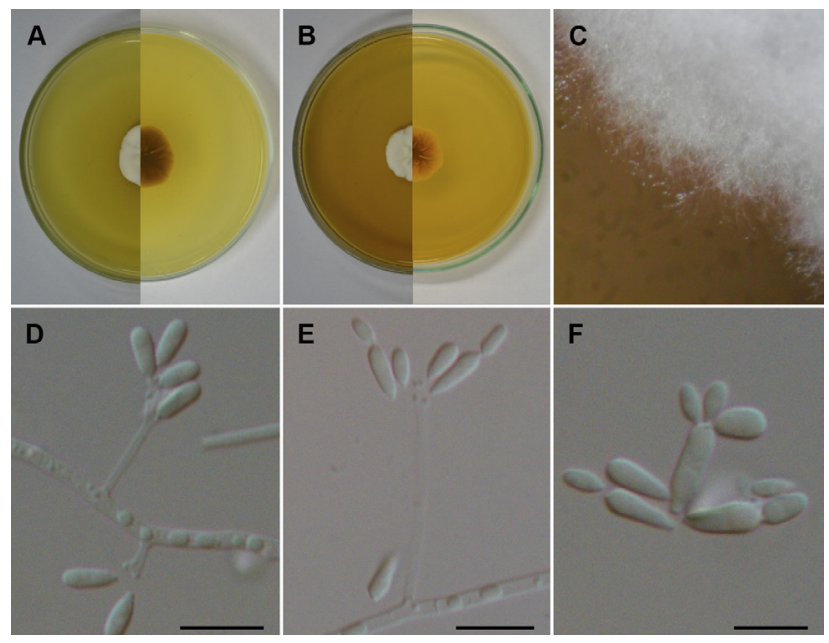

Figure 1. Quambalaria fabacearum (URM 7756 - ex-type culture). A. Culture on PDA. B. Culture on MEA. C. Detail of the colony on MEA. D. Conidiophores and conidia. E. Conidia forming acropetal chains. F. Primary conidia forming secondary conidia. Scale bars: D-E: $10 \mu \mathrm{m}$; F: $5 \mu \mathrm{m}$.

\section{Diaporthe inconspicua R.R. Gomes, C. Glienke \& Crous, Persoonia 31: 23. 2013, emend.}

\section{Fig. 3}

Description: Conidiomata pycnidial, superficial to embedded on PDA, solitary or aggregated, erumpent, dark brown to black, globose with ostioles, 424-954 × 371-742 $\mu \mathrm{m}$, exuding yellowish conidial mass from the ostioles. Conidiophores hyaline, 0-2-septate, cylindrical, smooth, straight to sinuous, occurring in dense clusters, sometimes branched, 11-21.5 × 2-2.5 $\mu \mathrm{m}$. Conidiogenous cells phialidic, cylindrical, terminal, (2-)5.5-8.5(-14.5) × (1.5-)2-2.5 $\mu \mathrm{m}$. Paraphyses not observed. Alpha conidia, hyaline, smooth, aseptate, ellipsoidal to fusoid, nonguttulate and acute at both ends, 5.5-6.5 × 1.5-2 $\mu \mathrm{m}$. Beta conidia hyaline, aseptate, nonguttulate, filiform, straight to curved, tapering towards the apex, base truncate, (17.5-)20-26(-28) × 1-1.5 $\mu \mathrm{m}$. Sexual morph not observed.

Cultures (in the dark, $25^{\circ} \mathrm{C}, 2 \mathrm{wk}$ ): On OA spreading, flat with sparse aerial mycelium, surface cream-colored in the centre, umber in the outer region. On PDA surface and reverse, cream-colored to dirty white with sparse aerial mycelium. On MEA, with sparse aerial mycelium, surface becoming folded, dirty white in the centre, sienna in the outer region, and luteous in the reverse of the colony (from Gomes et al. 2013). 


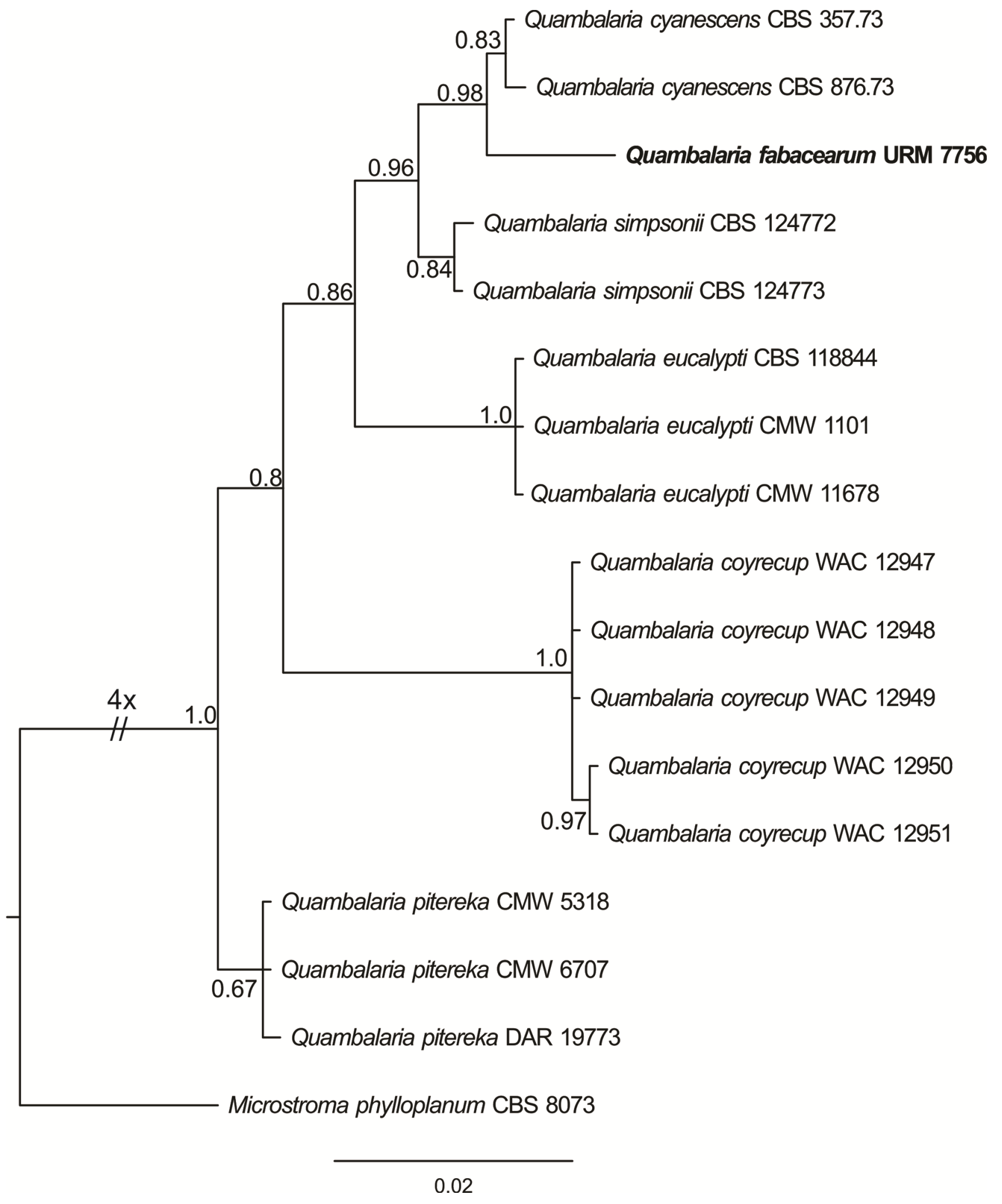

Figure 2. Bayesian Inference tree obtained from data set of 15 taxa including representatives of genera Quambalaria and a potential new species comparing ITS rDNA and LSU rDNA (concatenated) with Microstroma phylloplanum (Microstromatales) as outgroup. 
Material examined: Diaporthe inconspicua. BRAZIL. Paraíba: Santa Teresinha, Tamanduá farm $\left(7^{\circ} 1.524^{\prime} \mathrm{S}\right.$ $37^{\circ} 23.518^{\prime} \mathrm{W}$ ), isolated as an endophyte from branches of Poincianella pyramidalis (Tul.) L. P. Queiroz (Fabaceae), May 2013, J.D.P. Bezerra (strains: URM 7775, URM 7776, URM 7777; isolates: G40, B29, G41, G2, G31, G20, B11, G28, G33, B15, G52, B12, E12, G12).

GenBank accession numbers: URM 7775: ITS MG696783, LSU MG696791, CaM MG710389, H3 MG710397, tef1- $\alpha$ MG710412, TUB2 MG710393. URM 7776: ITS MG696772, LSU MG696790, CaM MG710391, H3 MG710410, tef1- $\alpha$ MG710414, TUB2 MG710395. URM 7777: ITS MG696773, LSU MG696799, CaM MG710390, H3 MG710406, tef1- $\alpha$ MG710413, TUB2 MG710394. G40: ITS MG696767, LSU MG696797, CaM MG710388, tef1- $\alpha$ MG710411, TUB2 MG710392. B29: ITS MG696768, LSU MG696787, H3 MG710402. G41: ITS MG696769, LSU MG696798, H3 MG710401. G2: ITS MG696770, LSU MG696792, H3 MG710405. G31: ITS MG696771, LSU MG696795, H3 MG710409. G20: ITS MG696774, LSU MG696793, H3 MG710396.
B11: ITS MG696775, LSU MG696784, H3 MG710398. G28: ITS MG696776, LSU MG696794. G33: ITS MG696777, LSU MG696796, H3 MG710400. B15: ITS MG696778, LSU MG696786, H3 MG710399. G52: ITS MG696779, LSU MG696800, H3 MG710407. B12: ITS MG696780, LSU MG696785, H3 MG710403. E12: ITS MG696781, LSU MG696788, H3 MG710408. G12: ITS MG696782, LSU MG696789, H3 MG710404.

Notes - Diaporthe inconspicua was proposed by Gomes et al. (2013) for some sterile endophytic isolates from medicinal plants Maytenus ilicifolia and Spondias mombin in Brazil, based on phylogenetic analyses of five genes. Gomes et al. (2013) did not include a morphological description because the ex-type strain and other isolates were sterile in culture media. Based on current phylogenetic inferences using three genes, some endophytes isolated from Poincianella pyramidalis growing in a tropical dry forest (Caatinga) in Brazil demonstrated high identity and phylogenetic relationship (Fig. 4) with D. inconspicua ex-type strain (CBS 133813). Some of these isolates from P. pyramidalis sporulated in
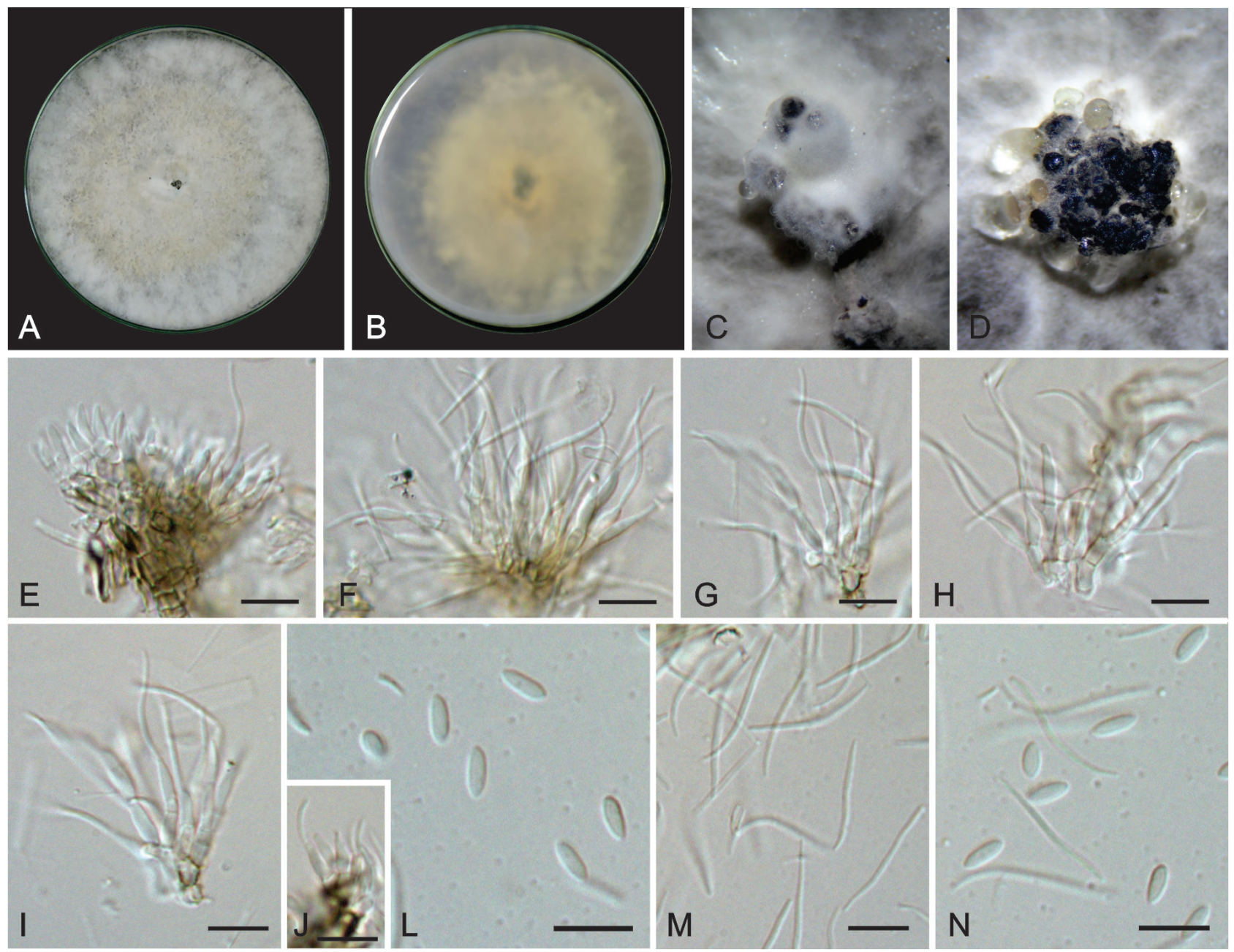

Figure 3. Diaporthe inconspicua (URM 7775). A-B. Culture on PDA after 15d. C-D. Pycnidial conidiomata on PDA after 30d. E-J. Conidiophores, conidiogenous cells and beta conidia. L. Alpha conidia. M. Beta conidia. N. Alpha and beta conidia. Scale bars: $10 \mu \mathrm{m}$. 


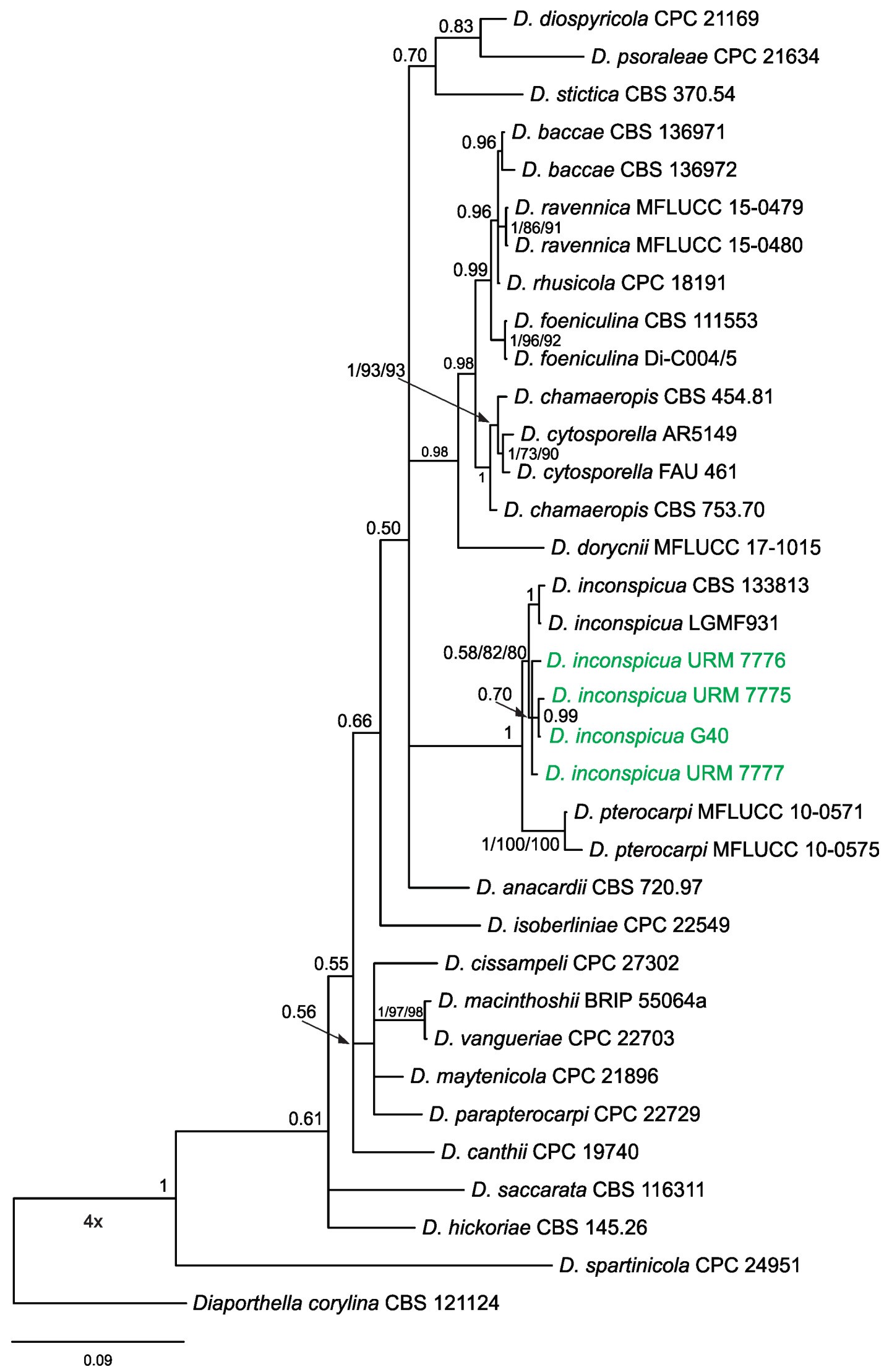

Figure 4. Bayesian Inference tree obtained from concatenated dataset of ITS rDNA, tef1- $\alpha$ and TUB2 sequences of 24 species of the genera Diaporthe with Diaporthella corylina (CBS 121124) as outgroup. Posterior probabilities from BI, ML and MP bootstrap support values above $70 \%$, respectively, are shown at nodes. Strains obtained in the current study are in green. 
culture media, and here is presented a morphological description for D. inconspicua. Diaporthe inconspicua is phylogenetically related to $D$. pterocarpi, but differs in size of pycnidia (100-120 $\mu \mathrm{m}$ diam.), conidiophores (10-15 $\times 1-2 \mu \mathrm{m})$, and alpha conidia $(6-7 \times 2.5 \mu \mathrm{m})$, and by the absence of beta conidia (Udayanga et al. 2012). Also, the host plants of $D$. pterocarpi are known to be species of Aloe, Jatropha, Ougeinia and Pterocarpus (Udayanga et al. 2012), while $D$. inconspicua has been related to an endophyte from species of Maytenus and Spondias (Gomes et al. 2013), and Poincianella, as reported here for the first time.

\section{Neopestalotiopsis brasiliensis Abreu V.P., Rosado} A.W.C. \& Pereira O.L., sp. nov.

\section{MycoBank MB 823488, Fig. 5}

Etymology: the name "brasiliensis" refers to Brazil, the country where the fungus was collected.

Description: Conidiomata sporodochial on PDA, globose, solitary or aggregated, semi-immersed, black, exuding globose dark brown to black conidial masses. Conidiophores and conidiogenous cells not observed in vitro. Conidia fusoid, ellipsoid, straight to slightly curved, 4-septate, 20-26.5 × 5-8.5 $\mu \mathrm{m}$; basal cell conic to obconic, hyaline, smooth and thin-walled, 3-5 $\mu \mathrm{m}$ long; three median cells doliiform, 13-16.5 $\mu \mathrm{m}$ long, smooth, concolourous or versicolourous, brown, septa darker than the rest of the cell (second cell from base pale brown, 4-6 $\mu \mathrm{m}$ long; third cell darker brown, 4-5.5 $\mu \mathrm{m}$ long; fourth cell brown, 4-6 $\mu \mathrm{m}$ long); apical cell 3-5 $\mu \mathrm{m}$ long, hyaline, cylindrical to subcylindrical, thinand smooth-walled; with 1-3 tubular apical appendages, arising from the apical crest, unbranched, filiform, flexuous 8.5-15 $\mu \mathrm{m}$ long; basal appendage single, tubular, unbranched, centric, 2-5 $\mu \mathrm{m}$ long. Sexual morph not observed.

Cultures (under a 12 -h photoperiod, $25^{\circ} \mathrm{C}, 1 \mathrm{wk}$ ): colonies on PDA attaining $73 \mathrm{~mm}$ diam, with undulate edge, whitish, with dense aerial mycelium on the central surface and dark brown to black conidial masses. Colonies on MEA attaining $68 \mathrm{~mm}$ diam, with undulate edge, whitish, with dense aerial mycelium on the central surface and dark brown to black conidial masses.

Pathogenicity test: causing post-harvest rot disease, seven days after the inoculation of healthy ripe guava fruits.

Type: BRAZIL. Minas Gerais: Viçosa, on fruits of Psidium guajava L. (Myrtaceae), February 2014, V.P. Abreu (Holotype VIC44200; Culture ex-type COAD 2166).

GenBank accession numbers: COAD 2166 (ex-type): ITS MG686469, TUB2 MG692400, tef1- $\alpha$ MG692402.

Notes: A phylogenetic tree was generated based on reference/type sequences of the 31 Neopestalotiopsis spp. described to date (Maharachchikumbura et al. 2014; Crous et al. 2015; Ayoubi \& Soleimani 2016; Hyde et al. 2016; Jayawardena et al. 2016; Silvério et al. 2016; Akinsanmi et al. 2017). Based on phylogenetic analysis, Neopestalotiopsis brasiliensis is closely related to $N$. chrysea, $N$. umbrinospora, N. asiatica and N. macadamiae (Fig. 6). Morphologically, $N$. brasiliensis differs from $N$. chrysea, $N$. umbrinospora, $N$. asiatica (Maharachchikumbura et al. 2014) and N. macadamiae (Akinsanmi et al. 2017) by having shorter apical appendages (8.5$15 \mu \mathrm{m})$ and a shorter basal appendage $(2-5 \mu \mathrm{m})$. The number of apical appendages for $N$. brasiliensis and $N$. umbrinospora range $1-3$, which is slightly fewer than other species of the genus. Neopestalotiopsis brasiliensis has larger conidia $(20-26.5 \times 5-8.5 \mu \mathrm{m})$ than $N$. chrysea, $N$. umbrinospora, $N$. asiatica and $N$. macadamiae. In addition, $N$. brasiliensis possesses versicolourous or concolourous median cells.
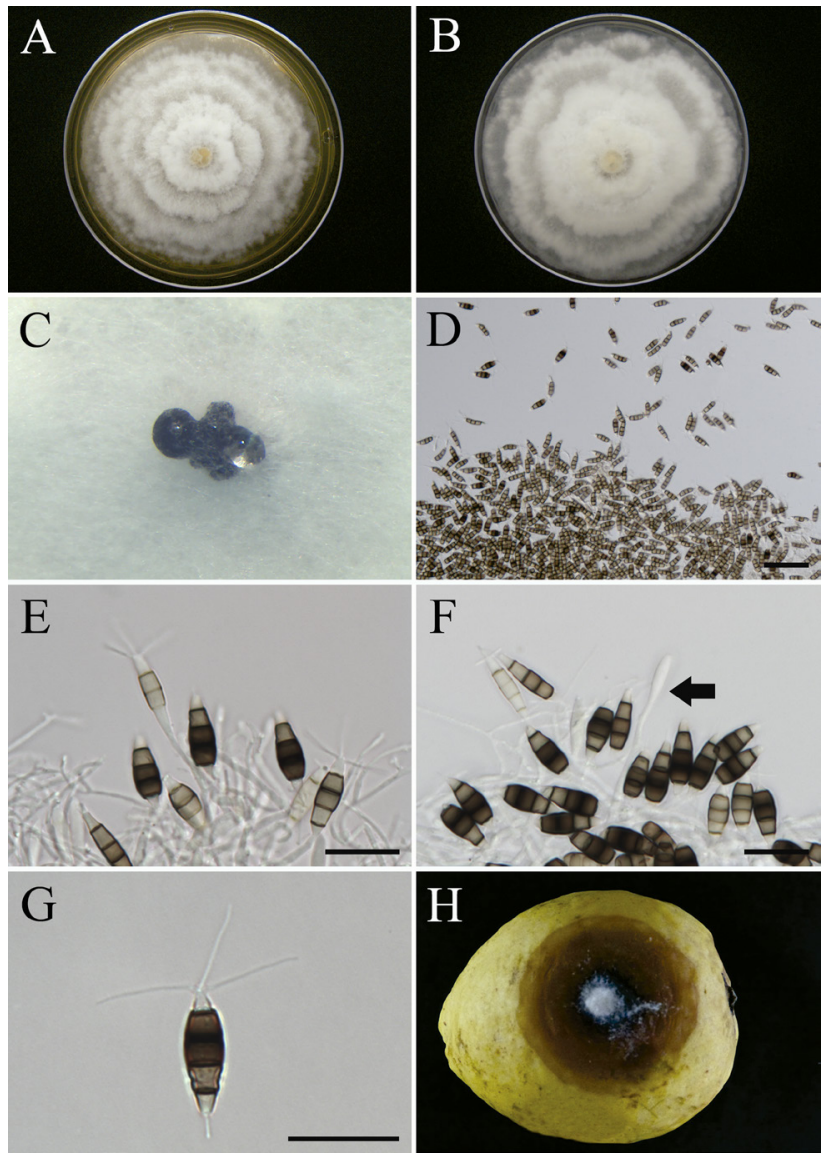

Figure 5. Neopestalotiopsis brasiliensis (COAD 2166 - ex-type culture). A. Colony on MEA after seven days at $25^{\circ} \mathrm{C}$. B. Colony on PDA after seven days at $25^{\circ} \mathrm{C}$. C. Conidiomata sporulating on PDA. D. Conidial masses. E. Conidia formation in vitro. F. Detail of conidial formation in vitro (arrow). G. Conidium. H. Pathogenicity test seven days after inoculation. Scale bars: D: $50 \mu \mathrm{m}$; E-G: $20 \mu \mathrm{m}$. 


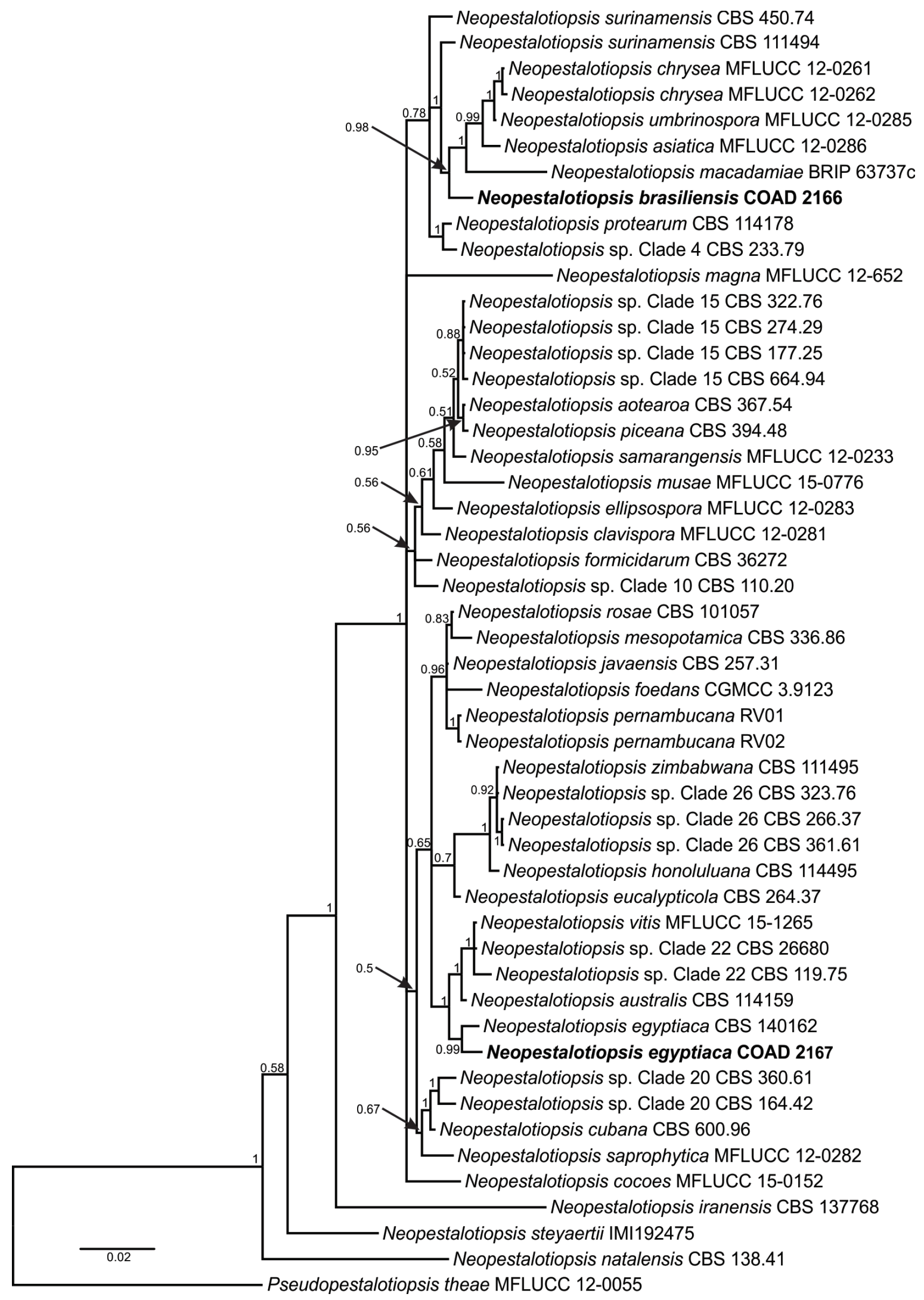

Figure 6. Multilocus phylogenetic tree inferred from Bayesian analysis based on the combined sequences of the ITS rDNA, TUB2 and tef1- $\alpha$. The Bayesian posterior probabilities are indicated next to the nodes. The tree was rooted with Pseudopestalotiopsis theae MFLUCC 12-0055. The species in this study are highlighted in bold. Neopestalotiopsis spp. Clade 4, Clade 10, Clade 15, Clade 20 and Clade 26 is according to Maharachchikumbura et al. (2014). 
Neopestalotiopsis egyptiaca A.M. Ismail, G. Perrone \& Crous Persoonia 35:271. 2015.

Fig. 7

Description (COAD 2167): Conidiomata sporodochial on PDA, globose, solitary, semi-immersed, black, exuding globose, dark brown to black conidial masses. Conidiophores indistinct, reduced to conidiogenous cells. Conidiogenous cells discrete, cylindrical, hyaline, smooth, proliferating 2 times percurrently at apex, 6-11 × 2-3 $\mu \mathrm{m}$. Conidia fusoid, ellipsoid, smooth, straight and sometimes slightly curved, 4-septate, 21.5-28 × 5-7 $\mu \mathrm{m}$; basal cell conic, hyaline, smooth and thin-walled, 3-5.5 $\mu \mathrm{m}$ long; three median cells doliiform, 13.5-17 $\mu \mathrm{m}$ long, versicolourous, brown, septa darker than the rest of the cell (second cell from the base 4-6.5 $\mu \mathrm{m}$; third cell 4-6 $\mu \mathrm{m}$; fourth cell 4-6 $\mu \mathrm{m}$ ); apical cell 3.5-6 $\mu \mathrm{m}$ long, hyaline, cylindrical to subcylindrical, thin- and smoothwalled; with 1-3 tubular apical appendages, arising from the apical crest, unbranched, filiform, flexuous 11-21 $\mu \mathrm{m}$
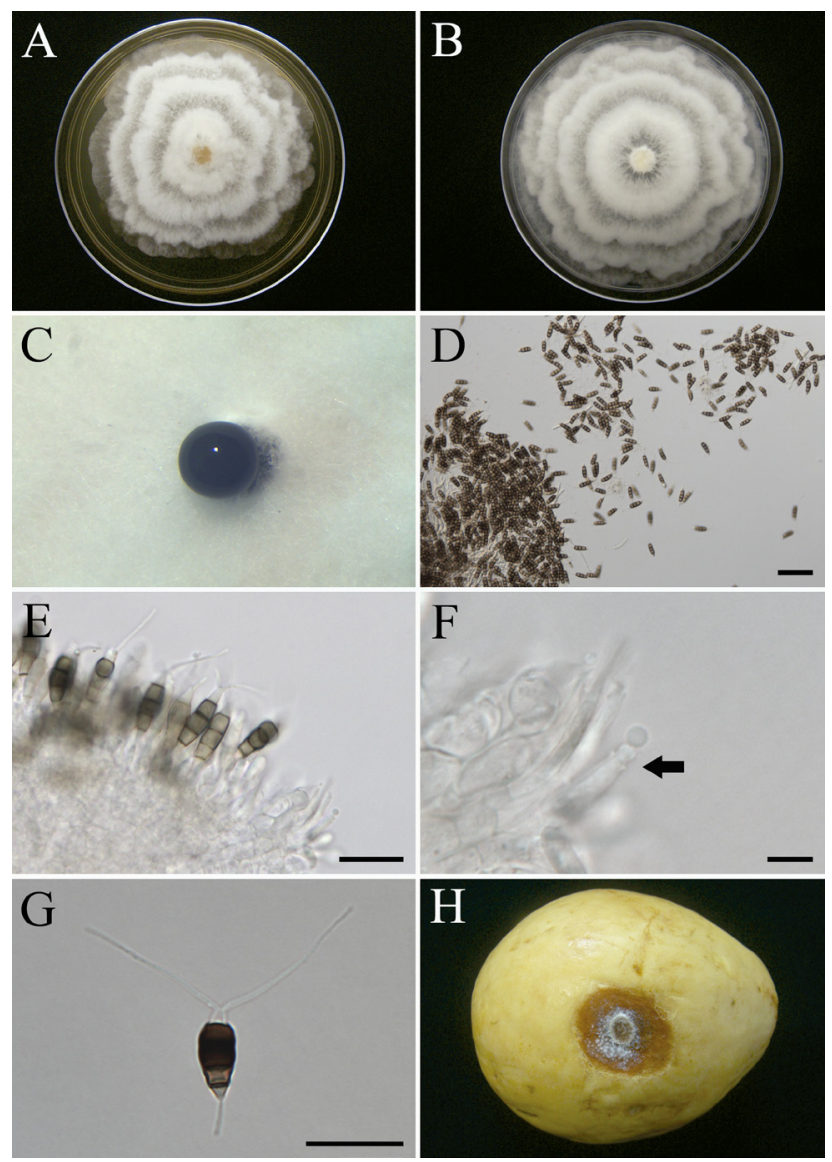

Figure 7. Neopestalotiopsis egyptiaca (COAD 2167). A. Colony on MEA after seven days at $25^{\circ} \mathrm{C}$. B. Colony on PDA after seven days at $25^{\circ}$ C. C. Conidioma sporulating on PDA. D. Conidial masses. E. Conidiogenous cells. F. Detail of annellidic conidiogenous cell (arrow). G. Conidium. H. Pathogenicity test seven days after inoculation. Scale bars: D: $50 \mu \mathrm{m}$; E, G: $20 \mu \mathrm{m}$; F: $10 \mu \mathrm{m}$. long; basal appendage single, tubular, unbranched, centric, 1.5-5.5 $\mu \mathrm{m}$ long. Sexual morph not observed.

Cultures (under a 12 -h photoperiod, $25^{\circ} \mathrm{C}$, one week): Colonies on PDA attaining $78 \mathrm{~mm}$ diam after seven days at $25{ }^{\circ} \mathrm{C}$, with undulate edge, whitish, with dense aerial mycelium on the surface and dark brown to black conidial masses. Colonies on MEA attaining $68 \mathrm{~mm}$ diam after seven days at $25{ }^{\circ} \mathrm{C}$, with undulate edge, whitish, with dense aerial mycelium on the surface and dark brown to black conidial masses.

Pathogenicity test: Causing post-harvest rot disease, seven days after the inoculation of health ripe guava fruits.

Material examined: Neopestalotiopsis egyptiaca. BRAZIL. Minas Gerais: Viçosa, on fruits of Psidium guajava L. (Myrtaceae), February 2014, V.P. Abreu (VIC 44201; COAD 2167).

GenBank accession numbers: COAD 2167: ITS MG686470, TUB2 MG692401, tef1- $\alpha$ MG692403.

Notes: Based on phylogenetic analyses, the isolate COAD 2167 grouped in a well-supported clade including the Neopestalotiopsis egyptiaca ex-type strain CBS 140162 (Fig. 6). Morphologically, N. egyptiaca COAD 2167 has smaller conidiogenous cells $(6-11 \times 2-3 \mu \mathrm{m})$, number of apical appendages ranging from $1-3$, larger conidia (21.5-28 $\times 5-7 \mu \mathrm{m})$, a little shorter apical appendage $(11-21 \mu \mathrm{m})$ and shorter basal appendage $(1.5-5.5 \mu \mathrm{m})$ than $N$. egyptiaca CBS 140162. However, there minor morphological differences are commonly observed on different isolates of the same Neopestalotiopsis species (Maharachchikumbura et al. 2014). Neopestalotiopsis egyptiaca is only reported causing leaf spot disease on Mangifera indica (Anacardiaceae) in Africa (Egypt) (Crous et al. 2015). To our knowledge, this is the first report of Neopestalotiopsis egyptiaca from the American continent. This is also the first report of the species causing postharvest rot disease on guava (Psidium guajava) fruits. These findings may be helpful for further studies on quarantine programs and management measures.

Umbelopsis isabellina (Oudem.) W. Gams, in Meyer \& Gams, Mycological Research 107(3): 349. 2003.

Fig. 8

Description: Colonies low, up to $4 \mathrm{~mm}$ in height, $7 \mathrm{~cm}$ diam., velvety, initially white becoming drab-grey to fuscous on MEA at $25^{\circ} \mathrm{C}$. Reverse slightly zoned and cream-colored. Sporangiophores simple or with simple branching (up to seven) arising from the same point, sympodial branching also observed, often swollen at the point of branching; 120-300 (-380) $\mu \mathrm{m}$ long, reaching 3-5 $\mu \mathrm{m}$ in width close to the base, 1-2 septate, rarely ( -4$)$, tapering gradually toward apex. Sporangia globose 7-18 $\mu \mathrm{m}$ diam., multispored, initially hyaline, becoming greyish, walls evanescent, infrequently collared. Columellae mostly inconspicuous or absent, when present in the larger sporangiophores they are very small, slightly convex, smooth-walled, $2-3 \mu \mathrm{m}$ in diam. 
Sporangiospores diverse in shape, mostly globose, $2-5 \mu \mathrm{m}$ in diam.; also ellipsoidal, $4.5 \times 2.5 \mu \mathrm{m}$, slightly angular, $3.5 \mu \mathrm{m}$ diam. Chlamydospores present in aerial mycelium, variable in shape, globose, subglobose and doliform. Zygosporangia not observed.

Cultures and temperature tests: On MEA at $10^{\circ} \mathrm{C}$, very limited growth $(2.2 \mathrm{~cm}$ in diam. in seven days, $<1 \mathrm{~mm}$ in height), no reproductive structures; at $15^{\circ} \mathrm{C}$, small colonies ( $<1 \mathrm{~mm}$ in height) with slow growth $(4.5 \mathrm{~cm}$ in diam. in seven days), weak sporulation, sporangiophores simple or slightly branched; at $20^{\circ} \mathrm{C}$, colonies growing up to 3 $\mathrm{mm}$ in height with fast growth (7 $\mathrm{cm}$ in five days), weak sporulation; at $25^{\circ} \mathrm{C}$, colonies growing $7 \mathrm{~cm}$ in four days and up to $3 \mathrm{~mm}$ in height, strong sporulation; at $35^{\circ} \mathrm{C}$, no growth and sporulation.

Material examined: Umbelopsis isabellina. BRAZIL. Pernambuco: Buíque, Catimbau National Park ( $8^{\circ} 36^{\prime} 35^{\prime \prime} S$ $37^{\circ} 14^{\prime} 40^{\prime \prime} \mathrm{W}$ ), isolated as an endophyte from leaves of
Tillandsia catimbauensis Bromeliaceae, K.T.L.S. Freire (strain: URM 7862; isolates: T71.211, T146.212, T145.224, T87.228, T169.253, T186.294).

GenBank accession numbers: URM 7862: ITS MH220327. T71.211: ITS MH220324. T146.212: ITS MH220325. T145.224: ITS MH220326. T186.294: ITS MH220328.

Notes - The type material of Umbelopsis isabellina was first reported from soil in The Netherlands and previously assigned to the genus Micromucor, later to Mortierella (Oudemans \& Koning 1902; Meyer \& Gams 2013) and now it is accepted as Umbelopsis (Spatafora et al. 2016). After the original description, there have been some reports from different substrates and hosts (Hoff et al. 2004; Budziszewska et al. 2010). In the semiarid region of Brazil, $U$. isabellina has been reported from soil samples (Upadhyay 1967). The phylogenetic inference obtained in this study (Fig. 9) using ITS sequences and
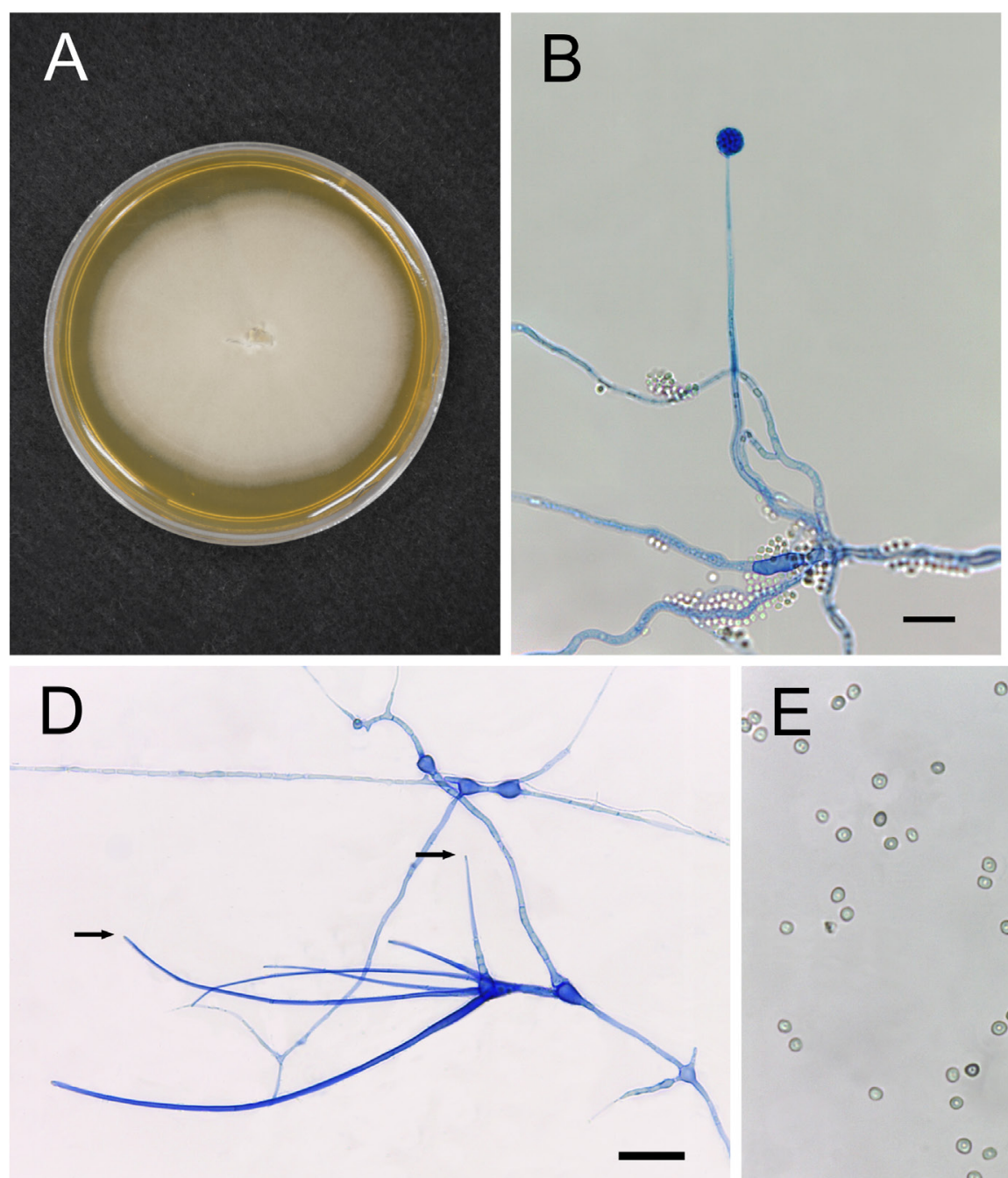

(2)
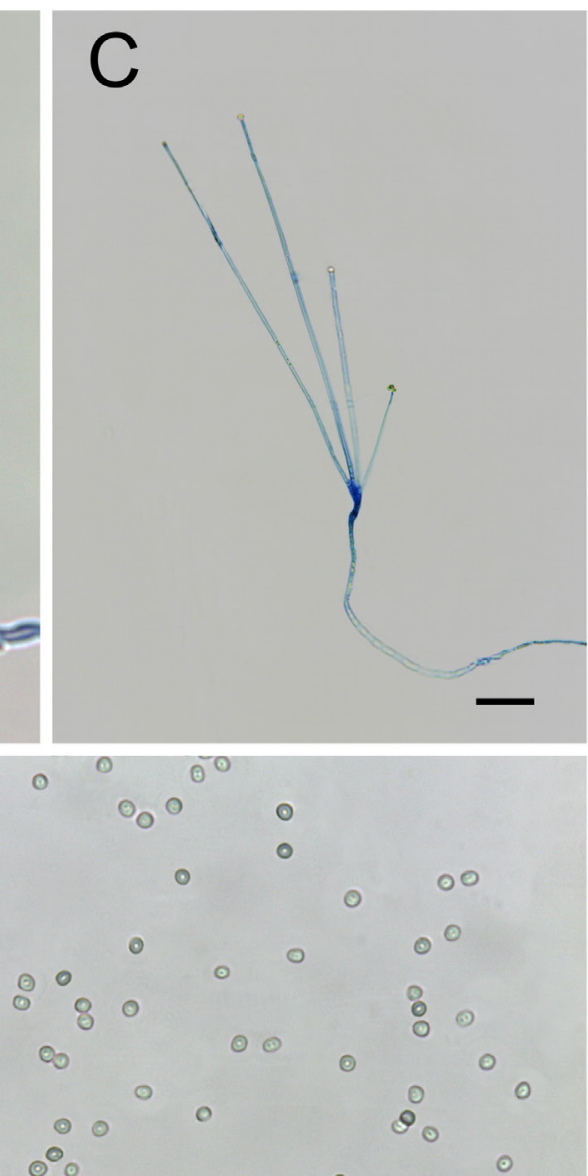

0

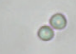

○

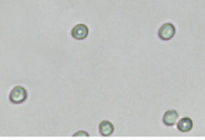

Figure 8. Umbelopsis isabellina (URM 7862). A. Colony surface on MEA after seven days. B. Simple sporangiophore with sporangium. C. Branched simple sporangiophores arising from the same point. D. Simple sporangiophores with inconspicuous columellae (arrows). E. Sporangiospores. Scale bars: 16, 25, 30 and $10 \mu \mathrm{m}$, respectively. 


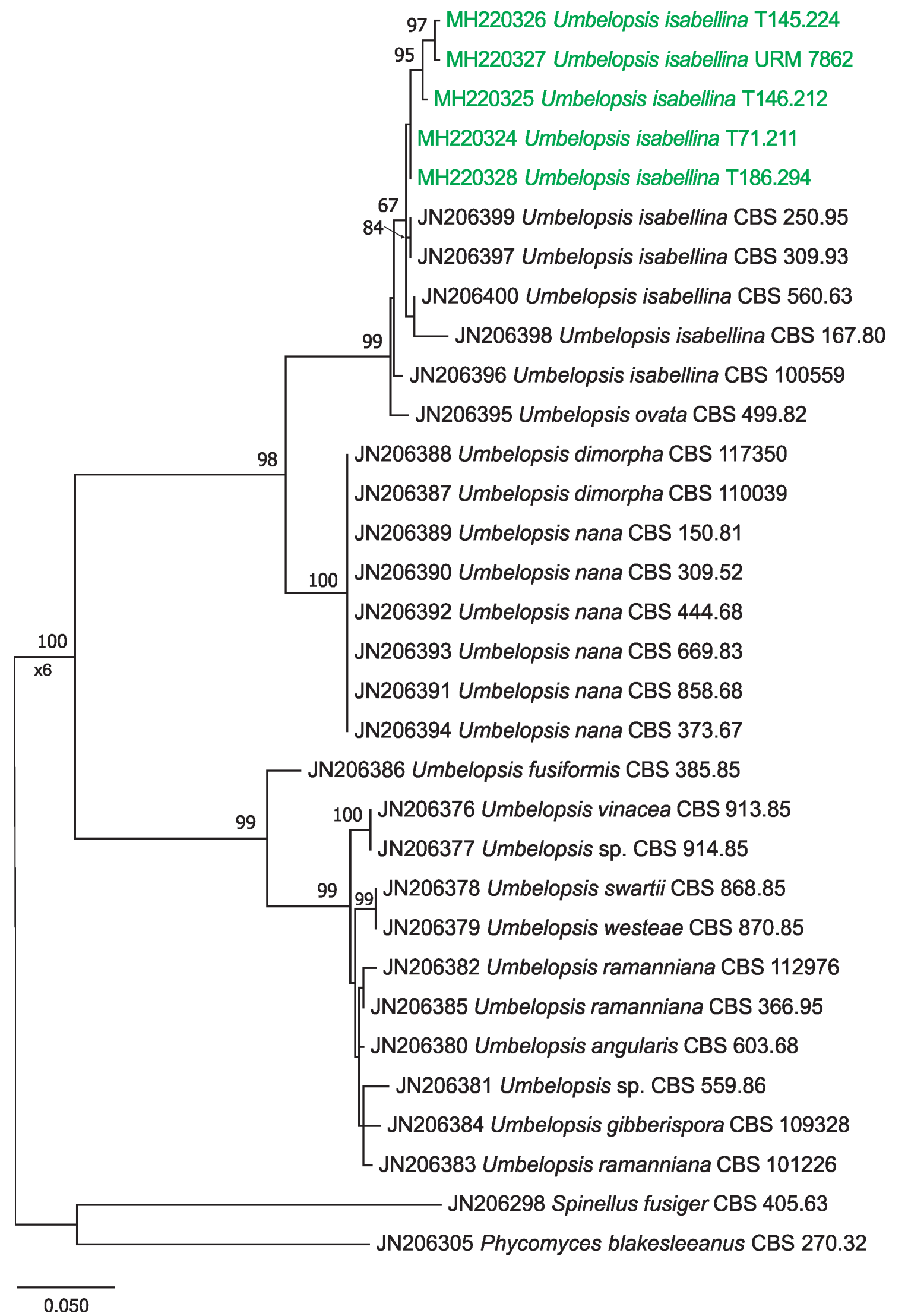

Figure 9. Maximum Likelihood (ML) tree obtained with MEGA 7 using ITS rDNA sequences of Umbelopsis species with Spinellus fusiger (CBS 405.63) and Phycomyces blakesleeanus (CBS 270.32) as outgroups. ML bootstrap values above $60 \%$ are shown at nodes. Isolates obtained in the current study are in green. 
morphological features, such as the colony characters of low or flat, zoned, at first white and later becoming dingy grey, spreading, velvety, sporangiophores simple or sympodially branched, tapering gradually toward apex, often septate, bearing sporangia terminally $(120-300 \mu \mathrm{m}$ long), sporangia globose, non-columellate or small columellae on dehiscence, sporangiospores (ellipsoidal, angular and mostly globose, $2-5 \mu \mathrm{m}$ in diam.), and the presence of chlamydospores, justified the identification of these endophytic isolates as U. isabellina (Meyer \& Gams 2013). The isolates obtained as endophytes from leaves of the bromeliad Tillandsia catimbauensis in the Brazilian tropical dry forest is the first record of this species as an endophytic fungus in Brazil.

\section{Acknowledgements}

JDPB, ALF, TGLO, CMSM, ARM, OMCM, KTLSF, CAFS and LMP thank CAPES, CNPq and FACEPE for financial support and scholarships. VPA, AWCR and OLP thank CAPES, CNPq and FAPEMIG for financial support.

\section{References}

Akinsanmi AO, Nisa S, Jeff-Ego OS, Shivas RG, Drenth A. 2017. Dry Flower Disease of Macadamia in Australia Caused by Neopestalotiopsis macadamiae sp. nov. and Pestalotiopsis macadamiae sp. nov. Plant Disease 101: 45-53.

Ayoubi N, Soleimani MJ. 2016. Strawberry fruit rot caused by Neopestalotiopsis iranensis sp. nov., and N. mesopotamica. Current Microbiology 72: 329-336.

Beer ZW, Begerow D, Bauer R, Pegg GS, Crous PW, Wingfield MJ. 2006. Phylogeny of the Quambalariaceae fam. nov., including important Eucalyptus pathogens in South Africa and Australia. Studies in Mycology 55: 289-298.

Braun U. 1998. Monograph on Cercosporella, Ramularia and allied genera (phytopathogenic hyphomycetes). Vol. II. Eching bei München, IHWVerlag.

Budziszewska J, Boulahdjel A, Wilk M, Wrzosek M. 2010. Soil zygomycetous fungi in Biebrza National Park (Northeast Poland). Polish Botanical Journal 55: 391-407.

Cheewangkoon R, Groenewald JZ, Summerell BA, Hyde KD, To-Anun C, Crous PW. 2009. Myrtaceae, a cache of fungal biodiversity. Persoonia 23: $55-85$.
Crous PW, Wingfield MJ, Roux JJ, et al. 2015. Fungal Planet description sheets: 371-399. Persoonia 35: 264-327.

Fan X, Xiao M, Kong F, Kudinha T, Wang H, Xu Y-C. 2014. A rare fungal species, Quambalaria cyanescens, isolated from a patient after augmentation mammoplasty - environmental contaminant or pathogen? PLOS ONE 9: e106949 doi: 10.1371/journal.pone. 0106949

Gomes RR, Glienke C, Videira SIR, Lombard L, Groenewald JZ, Crous PW. 2013. Diaporthe: a genus of endophytic, saprobic and plant pathogenic fungi. Persoonia 31: 1-41.

Hoff JA, Klopfenstein NB, McDonald GI, et al. 2004. Fungal endophytes in woody roots of Douglas-fir (Pseudotsuga menziesii) and ponderosa pine (Pinus ponderosa). Forest Pathology 34: 255-271.

Hoog GS, Vries GA. 1973. Two new species of Sporothrix and their relation to Blastobotrys nivea. Antonie van Leeuwenhoek 39: 515-520.

Hyde KD, Hongsanan S, Jeewon R, et al. 2016. Fungal diversity notes 367-490: taxonomic and phylogenetic contributions to fungal taxa. Fungal Diversity 80: 1-270.

Jayawardena RS, Liu M, Maharachchikumbura SSN, et al. 2016. Neopestalotiopsis vitis sp. nov. causing grapevine leaf spot in China. Phytotaxa 258: 63-74.

Maharachchikumbura SSN, Hyde KD, Groenewald JZ, Xu J, Crous PW. 2014. Pestalotiopsis revisited. Studies in Mycology 79: 121-186.

Meyer W, Gams W. 2013. Delimitation of Umbelopsis (Mucorales, Umbelopsidaceae fam. nov.) based on ITS sequence and RFLP data. Mycological Research 107: 339-350.

Oudemans CAA, Koning C. 1902. Prodrome d'une flore mycologique, obtenue par la culture sur gelatine preparee de la terre humeuse du Spanderswoud, pres de Bussum. Archives Neerlandaises des Sciences 2: 266-298.

Paap T, Burgess T, McComb JA, Shearer BL, Hardy GEStJ. 2008. Quambalaria species, including Q. coyrecup sp. nov., implicated in canker and shoot blight diseases causing decline of Corymbia species in the southwest of Western Australia. Mycological Research 112: 57-69.

Silvério ML, Calvacanti MAQ, Silva GA, Oliveira RJV, Bezerra JL. 2016. A new epifoliar species of Neopestalotiopsis from Brazil. Agrotrópica 28: 151-158.

Simpson JA. 2000. Quambalaria, a new genus of eucalypt pathogens. Australian Mycologist 19: 57-62.

Spatafora JW, Benny GL, Lazarus K, et al. 2016. A phylum-level phylogenetic classification of zygomycete fungi based on genome-scale data. Mycologia 108: 1028-1046.

Udayanga D, Liu X, Mckenzie EHC, Chukeatirote E, Hyde KD. 2012. Multi-locus phylogeny reveals three new species of Diaporthe from Thailand. Cryptogamie Mycologie 33: 295-309.

Upadhyay HP. 1967. Soil fungi from Northeast Brazil, III. Phycomycetes. Instituto de Micologia, Universidade Federal de Pernambuco 31: 49-62.In ses consuntum rei pravo, sa vivirtil vituus, ca; nos 